\title{
The phenomenon of deficient electron microprobe totals in radiation-damaged and altered zircon
}

\author{
Lutz Nasdala $^{\mathrm{a}, *}$, Andreas Kronz ${ }^{\mathrm{b}}$, Richard Wirth ${ }^{\mathrm{c}}$, Tamás Váczi ${ }^{\mathrm{a}}$, \\ Cecilia Pérez-Soba ${ }^{d}$, Arne Willner ${ }^{\mathrm{e}}$, Allen K. Kennedy ${ }^{\mathrm{f}}$ \\ ${ }^{a}$ Institut für Mineralogie und Kristallographie, Universität Wien, Austria \\ ${ }^{\mathrm{b}}$ Geowissenschaftliches Zentrum, Georg-August-Universität Göttingen, Germany \\ ${ }^{\mathrm{c}}$ Helmholtz-Zentrum Potsdam, Deutsches GeoForschungsZentrum, Potsdam, Germany \\ ${ }^{\mathrm{d}}$ Departamento de Petrología y Geoquímica, Universidad Complutense, Madrid, Spain \\ ' Institut für Geologie, Mineralogie und Geophysik, Ruhr-Universität Bochum, Germany \\ ${ }^{\mathrm{f}}$ Department of Applied Physics, Curtin University of Technology, Perth, WA, Australia
}

\begin{abstract}
The phenomenon of deficient electron microprobe analyses, with sums of analyzed constituents often below $95 \mathrm{wt} \%$, is assigned to the analysis of altered, porous minerals. With the example of three zircon populations we show that low totals are related to textural features (i.e., numerous pores of tens to hundreds of nanometers size) as well as to the chemical composition (i.e., water content well within the wt $\%$ range, which may affect partial sample degradation under the electron beam). The formation of the spongy texture is explained by the alteration of a previously radiation-damaged and, thus, volumeexpanded material in a fluid-driven replacement reaction. The smaller volume of the reaction product (crystalline, non volume-expanded zircon) accounts for the formation of numerous voids and pores, which are perfect candidates for the incorporation of water. The alteration has also resulted in uptake of non-formula elements such as Al, P, Ca, Fe, Y, and REEs whereas $\mathrm{Si}$ and $\mathrm{Zr}$ are depleted. In one case, strong uptake of non-radiogenic $\mathrm{Pb}$ in altered zircon was observed. Because porous, low-total zircon has formed in secondary alteration process, its occurrence can be considered as an indicator of a secondary alteration history of the host rock. Low-total zircon is easily recognized by very low electron back-scatter intensities, which are closely related to the two main causes of the analytical shortfall (i.e., water content and porosity) and often lowered furthermore by the presence of light non-formula elements (especially $\mathrm{P}$ and $\mathrm{Fe}$ ) up to the wt $\%$ range.
\end{abstract}

\section{INTRODUCTION}

It has commonly been reported that electron microprobe analyses of radiation-damaged accessory minerals may yield analytical totals that are significantly below $100 \mathrm{wt} \%$, in some cases even well below $90 \mathrm{wt} \%$ (e.g., Medenbach, 1976; Speer, 1982; Törnroos, 1985; Pointer et al., 1988a; Smith et al., 1991; Förster, 1998; Mathieu et al., 2001). Such deficient totals were, for instance, ob-

\footnotetext{
* Corresponding author. Fax: +43142779532.

E-mail address: lutz.nasdala@univie.ac.at (L. Nasdala).
}

served for minerals of the zircon-thorite orthosilicate group (zircon, $\mathrm{ZrSiO}_{4}$; coffinite, $\mathrm{USiO}_{4}$; thorite, $\mathrm{ThSiO}_{4}$ ) and orthophosphates $\left(\mathrm{CePO}_{4}-\mathrm{YPO}_{4}\right)$. However, the majority of such analyses have been reported for zircon.

Causes of the deficient microprobe results are still under debate. Low analytical totals have mostly been ascribed to elevated concentrations of molecular water and/or hydroxyl groups (e.g., Törnroos, 1985; Smith et al., 1991; Geisler et al., 2003a). Correspondingly, the variation of analytical sums from $100 \mathrm{wt} \%$ was sometimes assigned to a hypothetical " $\mathrm{H}_{2} \mathrm{O}$ ", (e.g., Johan and Johan, 2005; Utsunomiya et al., 2007). This, however, appears to be somewhat questionable, as the assignment is based on an assumption 
without analytical verification. Also, calculated $\mathrm{H}_{2} \mathrm{O}^{*}$ values of as high as $18.4 \mathrm{wt} \%$ (Johan and Johan, 2005) would imply that the water content of that particular zircon sample has exceeded $50 \mathrm{~mol} \%$, which appears unlikely. Rubin et al. (1989) suggested that hydrous species may contribute to low totals not only because they are not analyzed in the electron microprobe but also by causing mineral degradation under the electron beam. Breiter et al. (2006) concluded that low totals cannot solely be explained by the presence of water but might also be due to fluorine and other elements not analyzed. Other interpretations include the presence of sub- $\mu \mathrm{m}$-sized voids (Pointer et al., 1988b) and structural vacancies (Kempe et al., 2000). Pérez-Soba et al. (2007) proposed that the presence of notable quantities of divalent (such as $\mathrm{Ca}, \mathrm{Fe}$ ) and trivalent cations (such as rare earth elements) in low-total zircon may be accompanied, and charge-compensated, by oxygen defects, which also contribute to analytical deficiencies.

Interestingly, there is an accompanying phenomenon: Low totals were always detected in interior regions of zircon crystals that appeared notably darker in back-scattered electron (BSE) images than neighbouring regions of the same crystal (Peterman et al., 1986; Pointer et al., 1988b; Smith et al., 1991; Kempe et al., 2000; Willner et al., 2003). As above, the causes of the anomalously low BSE intensity have remained controversial. In the present study, we have investigated three zircon samples with deficient electron microprobe totals. Apart from chemical analyses and imaging by electron microprobe, the structural and micro-textural state of samples was studied using transmission electron microscopy (TEM) and micro-spectroscopic techniques. With this present study we tried to address both the low totals and the "unusual" BSE intensities. We aim to contribute to the understanding of the physical causes of the deficient totals and unusually low BSE intensities as well as the formation of zircon samples exhibiting these phenomena.

\section{SAMPLES AND PREPARATION}

We have investigated three populations of zircon grains that frequently have low analytical totals. The first sample consists of late Archaean (age $\sim 2.65 \mathrm{Ga}$ ) zircon crystals $(>500 \mu \mathrm{m}$ fraction) from a late monzogranite (Sample No. W64), which has intruded tonalitic gneisses at the southern rim of the Jack Hills in the northern Yilgarn Craton, Western Australia (for geological setting and geochronology see Pidgeon and Wilde, 1998). A second population of zircon grains $(8-12 \mu \mathrm{m}$ fraction) was separated from an upper Riphean (Sample No. 32) and a middle Riphean sandstone (Sample No. 40), located about $100 \mathrm{~km}$ southwest of the city of Beloretsk (southern Ural; for more details see Willner et al., 2003). These authors reported notably discordant ${ }^{207} \mathrm{~Pb} /{ }^{26} \mathrm{~Pb}$ zircon ages compatible with crystallization in the age range $1.8-2.3 \mathrm{Ga}$. The third group of zircon crystals (Sample No. 87165; $<25 \mu \mathrm{m}$ fraction) comes from a Hercynian, coarse-grained leucogranite of the La Pedriza pluton in the Spanish Central System batholith, located about $50 \mathrm{~km}$ north-northwest of the city of Madrid (Pérez-Soba et al., 2007). Pérez-Soba (1992) reported a Rb-Sr isochron age of $307 \pm 3 \mathrm{Ma}$ for the La Pedriza pluton.
For comparison, "regular" zircon crystals (i.e., those with "normal" BSE intensities and analytical totals close to $100 \mathrm{wt} \%$ ) were also subjected to electron microprobe imaging. These samples included primary zoned, unaltered zircon crystals from a granite in the Jack Hills, Western Australia (Sample No. W34, courtesy of R.T. Pidgeon; for details and age see Pidgeon, 1992), zircon grains from a monzonite near the city of Freital, Meissen massif, Saxony, Germany (Sample No. Frei 1 , courtesy of T. Wenzel; for details see Wenzel et al., 1997; Nasdala et al., 1999), zircon grains from a charnockite-granite near the village of Kliprand, Namaqualand, South Africa (Sample No. Nam12, courtesy of A. Möller; for geological setting see Robb et al., 1999), and zircon crystals from a leucogranite north of the village of Dannemora, Adirondack Mountains, New Y ork State (Sample No. JHADK996, courtesy of J.M. Hanchar; for rock description see McLelland et al., 2001).

Zircon grains were embedded in araldite epoxy, ground to about half of their thicknesses to expose their internal textures, and polished. In the case of the Jack Hills zircon crystals, which are considerably larger in size than individual grains from the other localities, doubly polished thin sections ( $3 \mu \mathrm{m}$ thickness) attached to a glass slide were produced. Mounts were coated with carbon prior to electron microprobe imaging and analysis. For TEM analysis, site-specific TEM foils (sizes $\sim 10 \mu \mathrm{m}$, final thicknesses $\sim .1 \mu \mathrm{m}$ ) were cut out of the above sample mounts using a FEI FIB200 (for details of the focused ion beam technique see Wirth, 2004). For Sensitive High mass-Resolution Ion MicroProbe (SHRIMP) analysis of the isotopic composition, flat, polished sample mounts containing unknowns and the CZ3 reference zircon (Pidgeon et al., 1994) were prepared and coated with gold. For transmission infrared absorption analyses of La Pedriza zircon crystals, doubly polished plates (thickness $30 \mu \mathrm{m}$ ) parallel to the crystallographic $c$-axis were produced from single crystals and attached to an aluminium sample holder with a rectangular hole (40-18 $\mu \mathrm{m}$ size). Raman analyses were done on the electron microprobe and ion microprobe mounts after repolishing. However, analyses were placed at least $\sim 10 \mathrm{~m}$ away from the EMPA and SHRIMP spots, respectively, to avoid biased results due to potential structural changes caused by the electron or ion beam.

\section{EXPERIMENTAL TECHNIQUES}

Analysis of the chemical composition, and back-scattered electron (BSE), secondary electrons (SE), and cathodoluminescence (CL) imaging to visualize internal textures of crystals, were done using a JEOL 8900 RL electron probe microanalyser (EPMA). The BSE and CL images were obtained at $20 \mathrm{kV}$ and $2 \mathrm{nA}$. Chemical analyses were done with the EPMA operated at $20 \mathrm{kV}$ and a beam current of $8 \mathrm{nA}$. The electron beam was either focused to a $\sim 2 \mu \mathrm{m}$ spot, or defocused ( $15 \mu \mathrm{m}$ spot diameter). The calibrant materials included synthetic $\mathrm{ZrSiO}_{4}$ (for $\mathrm{Zr}$, $\mathrm{Si}$ ), $\mathrm{HfSiO}_{4}$ (for $\mathrm{Hf}$ ), $\mathrm{MgO}$ (for $\mathrm{Mg}$ ), $\mathrm{Al}_{2} \mathrm{O}_{3}$ (for $\mathrm{Al}$ ), $\mathrm{Y}-\mathrm{Al}$ garnet (for $\mathrm{Y}$ ), REE-CAS glasses (for REE; rare earth elements), $\mathrm{ThSiO}_{4}$ (for $\mathrm{Th}$ ), and $\mathrm{UO}_{2}$ (for $\mathrm{U}$ ); and natural apatite (for P), wollastonite (for $\mathrm{Ca}$ ), rhodonite (for $\mathrm{Mn}$ ), and 
hematite (for $\mathrm{Fe}$ ). Counting times were varied between $15 \mathrm{~s}$ (peak) and $2 \times 5$ s (lower and upper background) for the $\mathrm{K}_{\alpha}$ line of $\mathrm{Si}$, and $300 \mathrm{~s}$ (peak) and $2 \times 15 \mathrm{~s}$ (backgrounds) for the $\mathrm{M}_{\alpha}$ lines of $\mathrm{U}$ and $\mathrm{Th}$. Data were reduced using the CITZAF routine in the JEOL software, which is based on the $\Phi(\rho Z)$ correction method (Armstrong, 1991, 1995).

Oxygen was, as it is usual in silicate mineral analysis with the electron microprobe, calculated by stoichiometry. However, to check whether this has caused uncertainties (e.g., due to different oxidation states of the cations or the presence of water), it was appropriate to actually analyze oxygen. A number of samples were analyzed again including wavelength-dispersive X-ray analysis of oxygen. Oxygen measurements were performed using a W-Si multilayer detector (LDEl) with 2d-spacing of $60 \AA$ (see Armstrong, 1988; Rybka and Wolf, 1995). Operating conditions were $20 \mathrm{kV}$ and $20 \mathrm{nA}$ beam current measured at the Faraday cup. Synthetic $\mathrm{ZrSiO}_{4}$ was used as the oxygen calibrant. Calibrants and samples were simultaneously coated with carbon (note that due to the high mass-absorption coefficient of carbon on $\mathrm{O}-\mathrm{K}_{\alpha} \mathrm{X}$-rays, uniform coating thickness of reference and sample is crucial for reliable oxygen measurements in the EMPA). Counting times for $\mathrm{O}-\mathrm{K}_{\alpha}$ were $30 \mathrm{~s}$ (peak) and $2 \times 15 \mathrm{~s}$ (lower and upper background). Multiple measurements $(n=12)$ of the synthetic $\mathrm{ZrSiO}_{4}$ yielded $1 \sigma$ uncertainties of $\mathbf{0 . 0 1 1}(\mathrm{O}), \mathbf{0 . 0 4}$ (Si), and $0.008(\mathrm{Zr})$ per formula unit (based on a total of six ions per formula unit).

Analyses of $\mathrm{U}$ and $\mathrm{Th}$ concentrations and the $\mathrm{Pb}$ isotopic composition were made on a SHRIMP II at Curtin University of Technology, Perth. This system is operated by a consortium consisting of Curtin University, the University of Western Australia, and the Geological Survey of Western Australia. A primary, mass-filtered $\left(\mathrm{O}_{2}\right)$ beam ( $\sim 1 \mathrm{nA}$ ) was focused to a $\sim 1 \mu \mathrm{m}$ spot to sputter the sample surface. Data for each spot were collected in sets of eight scans through the mass range of $\mathrm{Zr}_{2} \mathrm{O}^{+},{ }^{24} \mathrm{~Pb}^{+}$, background, ${ }^{206} \mathrm{~Pb}^{+},{ }^{207} \mathrm{~Pb}^{+},{ }^{208} \mathrm{~Pb}^{+},{ }^{238} \mathrm{U}^{+},{ }^{248} \mathrm{ThO}^{+}$, and ${ }^{254} \mathrm{UO}^{+}$. For more experimental details see De Laeter and Kennedy (1998). Data were calibrated versus the CZ3 reference zircon (Pidgeon et al., 1994). The correction for common $\mathrm{Pb}$ was made from the observed ${ }^{2} \mathrm{~Pb}$ count rate.

Transmission electron microscopy was performed at Helmholtz-Zentrum Potsdam, using a FEI Tecnai $G^{2}$ F20 $\mathrm{X}$-Twin system operated at a voltage of $200 \mathrm{kV}$. The beam current was $.5 \mathrm{nA}$. The TEM analytical work included energy-dispersive chemical analyses, electron diffraction, electron energy loss spectroscopy (EELS), and bright field, high angle annular dark field (HAADF), and high-resolution electron microscopy (HREM) imaging.

Infrared (IR) absorption spectroscopy (transmission mode) was done with a Bruker Tensor 27 Fourier-transform infrared (FTIR) system equipped with Hyperion microscope. Spectra were recorded in the transmission mode, in the range $600-7000 \mathrm{~cm}{ }^{1}$. The spectral resolution was $2 \mathrm{~cm}{ }^{1}$. Pairs of spectra were obtained with the $E$ vector of the infrared light oriented parallel and perpendicular to the crystallographic $c$-axis. Raman spectra were obtained in quasi back-scattering geometry using an edge-filter based Renishaw RM1000 system equipped with Leica DMLM optical microscope. The Leica $50 x$ objective was used, and the system was operated in quasi-confocal mode; resulting in a lateral resolution of $\sim 4-5 \mu \mathrm{m}$. The spectral resolution was determined at $2.2 \mathrm{~cm}^{1}$. Spectra were excited with the $632.8 \mathrm{~nm}$ emission of a He-Ne laser $(\sim 8 \mathrm{~mW}$ at the sample surface).

\section{GENERAL CHARACTERIZATION OF LOW- TOTAL ZIRCON}

\subsection{Chemical composition}

A range of images of zircon crystals showing their internal textures is presented in Fig. 1a-g. Results of electron microprobe analyses are listed in Tables 1-3. All samples yielded, at least in some of their interior regions, analytical totals that were significantly deficient, i.e., in the range 91$97 \mathrm{wt} \%$. In samples W64 (Jack Hills) and 32/40 (Ural) these interior regions are rather small whereas zircon crystals from sample 87165 (La Pedriza) were commonly found to be entirely affected by the phenomenon of low totals. Low analytical totals were always detected in micro-areas characterized by very low BSE contrast (Fig. 1a-g); this observation will be discussed in more detail below.

In general, all samples are rich in actinides and contain comparably high levels of non-formula elements. Low-total areas in all samples contain higher levels of light elements (i.e., especially $\mathrm{P}$ and $\mathrm{Fe}$, also $\mathrm{Al}, \mathrm{Ca}$; Table 1 ) as well as $Y$ and some of the REEs, compared to neighbouring, un-altered areas of the same crystals. In contrast, heavy non-formula elements including $\mathrm{Hf}, \mathrm{Th}$, and $\mathrm{U}$ did not show such general trend. For instance, $\mathrm{U}$ and $\mathrm{Th}$ were found to be higher (Ural) and lower (Jack Hills), respectively, in the altered, low-BSE areas than in neighbouring unaltered areas. The main elements $\mathrm{Si}$ and $\mathrm{Zr}$ are considerably depleted in low-total areas.

Results presented in Table 1 are tainted with the important uncertainty that deficient totals are oxide sums which are not based on oxide analysis but merely cation analysis, with oxygen being calculated according to the concentration and valence of the cations. In order to get more reliable information, some samples were analyzed including the wavelength-dispersive analysis of oxygen (Table 2). Analogous to the routine electron microprobe analysis, oxygen was calculated from the observed cations (equivalent $\mathrm{O}$ in Table 2). These values were generally lower than measured $\mathrm{O}$ concentrations, with differences (excess $\mathrm{O}$ in Table 2) up to as high as $7.8 \mathrm{wt} \%$. We assign the excess oxygen, at least for a significant part, to water (see below); excess oxygen values were therefore transformed to hypothetical water $\left(\mathrm{H}_{2} \mathrm{O}^{*}\right)$ concentrations (Table 2$)$. The calculated excess $\mathrm{O}$ (Fig. 2) and $\mathrm{H}_{2} \mathrm{O}^{*}$ values (Table 2) show inverse correlation with $\mathrm{Zr}$ (and substitutes) and Si (and substitutes), respectively. This seems to support earlier hypotheses according to which low-total zircon was assumed to be notably hydrous. However, calculated analytical totals considering $\mathrm{H}_{2} \mathrm{O}^{*}$, for altered, low-BSE zircon, are still slightly (sample 87165 ) to strongly deficient (sample W64). We interpret the still deficient totals to indicate that water alone may be insufficient to explain the analytical shortfall. 
One potential reason for further deficiencies is seen in the fact that the impact of the electron beam is likely to cause dewatering and local disintegration of hydrous, low-total zircon. Aiming to check for such effects, analyses of crystal W64-11 were done with different energy densities of the electron beam but under otherwise uniform conditions (Table 2). After defocusing the electron beam to a $15 \mu \mathrm{m}$ spot diameter, considerably higher $\mathrm{O}$ concentrations (and hence higher calculated $\mathrm{H}_{2} \mathrm{O}^{*}$ values) but still deficient totals were detected in low-BSE zircon areas. These obser-
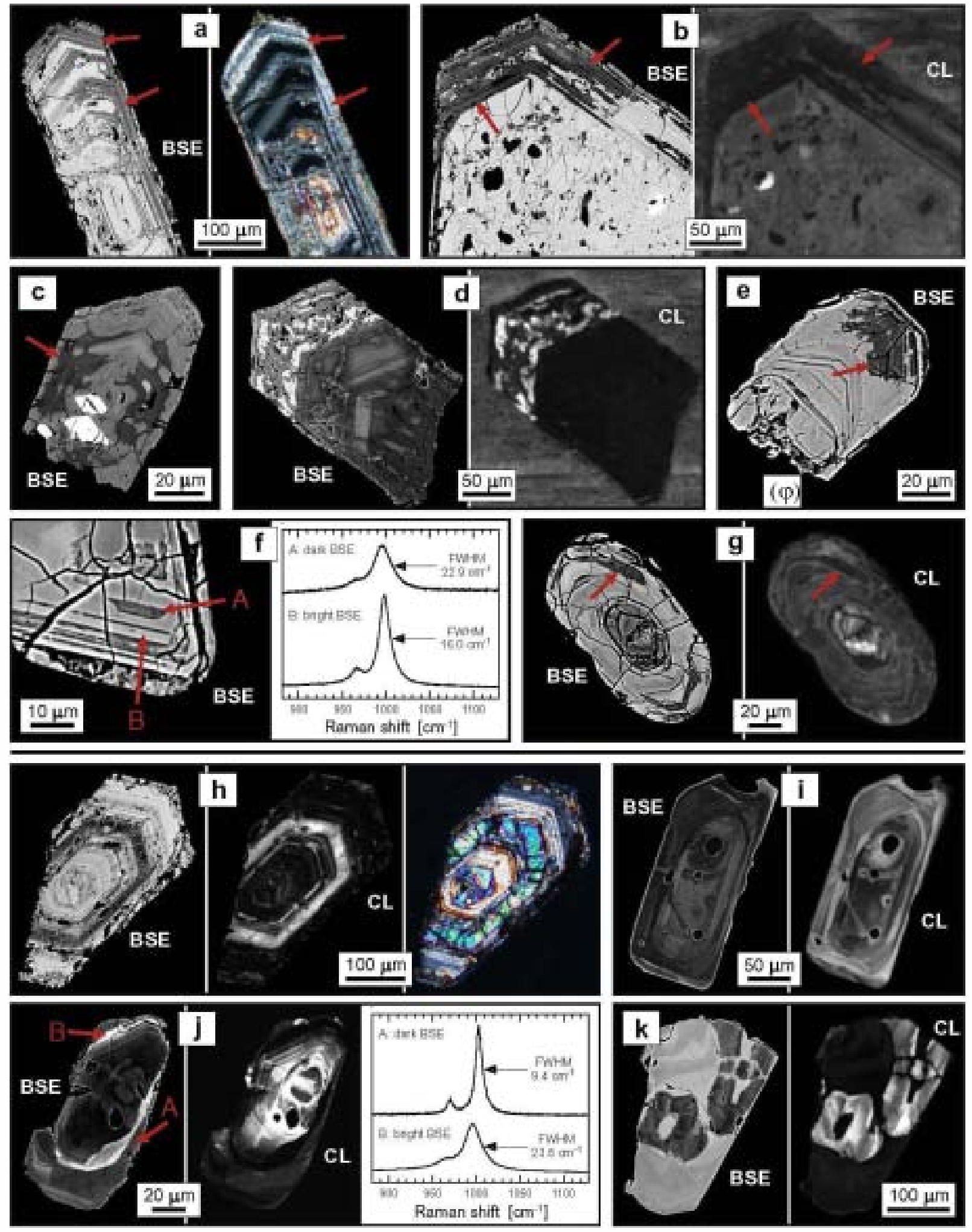
vations are explained by the consideration that the sample may have experienced local dewatering when analyzed regularly with a fully focused beam.

\section{2. $\mathrm{Pb}$ isotope composition}

In SHRIMP analyses of the $\mathrm{Pb}$ isotopic composition of zircon crystals from sample 87165 (La Pedriza) we found that bright-BSE areas are virtually free of non-radiogenic (i.e., common) $\mathrm{Pb}$ whereas porous, low-BSE areas contain significantly more common lead, with f206 values up to $\sim 10 \%$ (Table 3, Fig. 3). This is consistent with previous observations that zircon virtually excludes $\mathrm{Pb}$ in primary magmatic or metamorphic growth. The majority of $\mathrm{Pb}$ in zircon is normally implanted, resulting from the decay of unstable parent nuclei in the $\mathrm{U}$ and $\mathrm{Th}$ chains. In contrast, common $\mathrm{Pb}$ is mostly in the ppb range (e.g., Krogh, 1993; Wiedenbeck et al., 1995). We determined common $\mathrm{Pb}$ concentrations of $100-250 \mathrm{ppm}$ for porous, low-BSE areas in crystals from sample 87165 (Table 3).

Natural zircon with such high, and even higher, concentrations of common $\mathrm{Pb}$ have been studied before. All of these samples were found to be affected by secondary alteration processes (for instance, see Corfu, 1987; Mathieu et al., 2001) whereas, to the best of our knowledge, enhanced common $\mathrm{Pb}$ has never been observed in primary, unaltered zircon. From experiments to synthesize Pb-bearing zircon, Watson et al. (1997) concluded that $\mathrm{P}$ may charge-balance $\mathrm{Pb}^{2+}$ in zircon. This seems to be supported by our results, as enhanced common $\mathrm{Pb}$ is associated with high $\mathrm{P}$ concentrations (Table 3). However, variation of the $\mathrm{P}$ content in the La Pedriza zircon is rather moderate, in view of the extensive variations of common $\mathrm{Pb}$, whereas the Ural samples did not contain notable quantities of common $\mathrm{Pb}$ (Willner et al., 2003) but occasional very high $\mathrm{P}$ (Table 1). This suggests that the presence of $P$ (or, alternatively, $\mathrm{H}^{+}$; Watson et al., 1997) can be associated with, but is not sufficient to allow for incorporation of $\mathrm{Pb}$ into zircon. Our results and previous results indicate that the enhanced occurrence of common $\mathrm{Pb}$ is limited to zircon affected by secondary, fluid-driven alteration. This is perhaps explained by the strong trend that more $\mathrm{Pb}$ is incorporated in a wet than a dry environment, and normally low abundances of $\mathrm{Pb}$ in natural environments from which primary zircon grows whereas altering fluids are likely to bring more $\mathrm{Pb}$ into the system. This effect is in addition probably inversely correlated with temperature (Watson et al., 1997).

\subsection{The incorporation of hydrous species}

To check our and previous assumptions that low-total zircon is hydrated, analysis of hydrous species was first done by EELS spectra obtained in the TEM. A shoulder near $\sim 528 \mathrm{eV}$ at the oxygen K-edge (Fig. 4a) is characteristic of $\mathrm{OH} / \mathrm{H}_{2} \mathrm{O}$ (Wirth, 1997), which points to hydration of samples. However, both the assignment to either hydroxyl or molecular water and the quantification of the hydrous species from the EELS band integral are still problematic (Wirth, 1997). Therefore we applied IR absorption spectroscopy as a complimentary technique. Due to the rather limited spatial resolution of IR when compared to EELS, infrared spectroscopy can only be used if samples show the phenomenon of deficient totals over relatively large areas (i.e., several tens of $\mu \mathrm{m}$ across). This is the case for some crystals from sample no. 87165 (Fig. 1d).

Spectra (Fig. 4b) show the intense, asymmetric $\mathrm{O}-\mathrm{H}$ band without notable directional dependence that is typical of strongly radiation-damaged zircon (Caruba et al., 1985; Aines and Rossman, 1986; Nasdala et al., 2001b; Zhang et al., 2002). The assignment of this band, i.e., discriminating between either $(\mathrm{OH})$ groups or $\mathrm{H}_{2} \mathrm{O}$ molecules, is still controversial. The integrated area of the $\mathrm{O}-\mathrm{H}$ band (or more exactly, of the stretching fundamentals of hydroxyl groups and/or water molecules) in IR absorption spectra can be used to quantify the concentration of the hydrous species in unknown crystals. Using the equations of Libowitzky and Rossman (1996, 1997), remarkably uniform "water" concentrations in the range 5.0-6.8 wt\% were determined for six La Pedriza zircon crystals. The accuracy of these IR-based "water" values, however, is tainted with uncertainty: Nasdala et al. (2001b) found that in the case of radiation-damaged zircon, "water" concentrations determined from IR band intensities may differ appreciably from those determined by thermogravimetry (weight loss on heating) and moisture evolution analysis. The above "water" concentrations are hence only considered to indicate "semi-quantitatively" that hydrous species in the wt\% range are present.

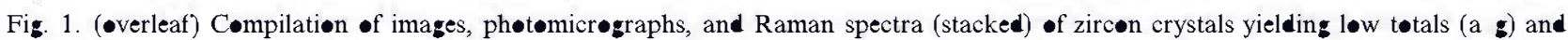

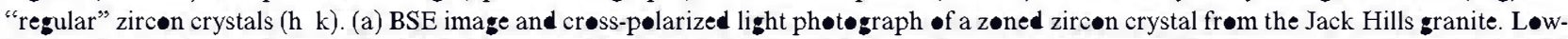

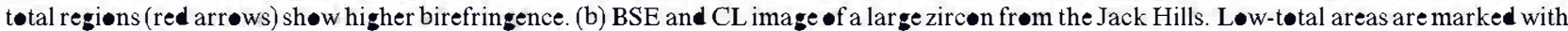

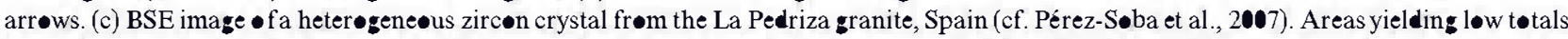

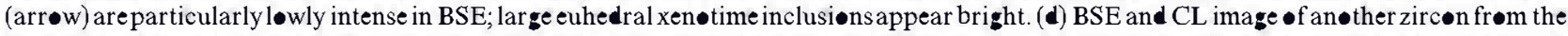

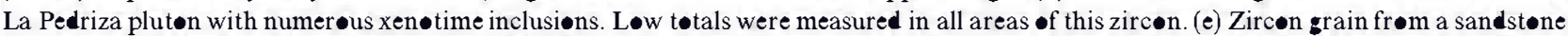
frøm the søuth-western Urals (cf. Willner et al., 2003) with a large alteratiøn patch that yielded løw tøals (arrøw). (f) BSE image and Raman

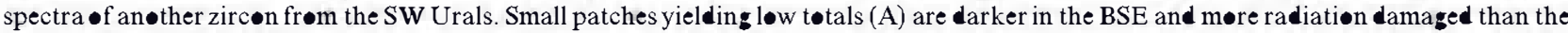

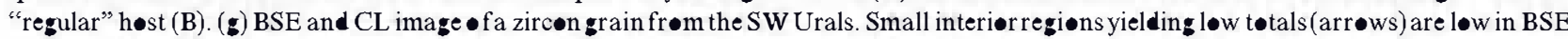

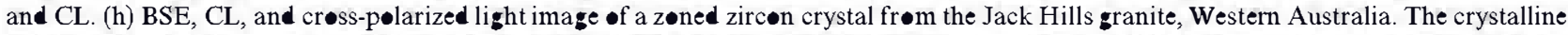

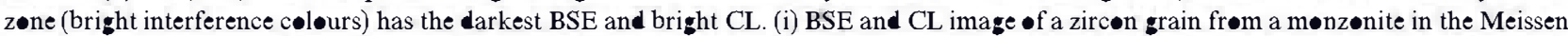

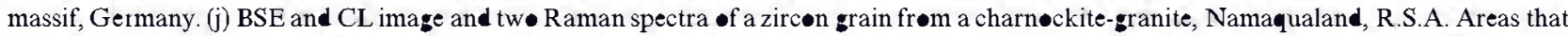
are bright in the BSE image (B) are strøngly radiation-damaged whereas less amaged areas (A) are rather møderately damaged. (k) BSE and CL

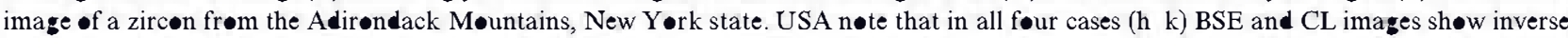
intensities. 
Table

Analytical results før zircon samples: BSE, electrøn micrøpr be data including calculated alpha doses, and Raman ata.

\begin{tabular}{|c|c|c|c|c|c|c|c|c|c|c|c|c|c|c|c|c|c|c|c|c|c|c|}
\hline \multirow[t]{2}{*}{ Area/sp•t } & \multirow[t]{2}{*}{ No. ${ }^{a}$} & \multirow[t]{2}{*}{$\mathrm{BSE}^{\mathrm{b}}$} & \multicolumn{18}{|c|}{ Electrøn micrøprøbe results $(w t \%)$} & \multirow[t]{2}{*}{$\alpha \operatorname{dose}\left(\times 10^{18} / \mathrm{g}\right)$} & \multirow[t]{2}{*}{$\mathrm{FWHM}^{\mathrm{c}}\left(\mathrm{cm}^{-1}\right.$} \\
\hline & & & $\mathrm{Al}_{2}$ & $\mathrm{Si}_{2}$ & $\mathrm{P}_{2}$ & $\mathrm{Ca}$ & Fee & $\mathrm{Y}$ & $\mathrm{Z}$ & $T_{h}$ & & $\mathrm{H}$ & $\mathrm{Fr}_{\mathrm{r}}$ & $\mathrm{Tm}_{2}$ & $\mathrm{Yh}$ & $\mathrm{Lu}_{2} \boldsymbol{\omega}_{3}$ & $\mathrm{Hf} \bullet_{2}$ & The & $\mathrm{U} \boldsymbol{\bullet}_{2}$ & T•t & & \\
\hline \multicolumn{23}{|c|}{ Sample W64: Jack Hills. Western Australia (Archaean) } \\
\hline W64 10a & 5 & dk. & $\mathbf{0 . 2 4}$ & 30.3 & 0.19 & 0.95 & $\bullet .2$ & 0.39 & 60.6 & (bdl) & $\bullet .22$ & $(\mathrm{bdl})$ & 0.27 & $(\mathrm{~b} d \mathrm{l})$ & 0.07 & $(\mathrm{~b} d \mathrm{l})$ & 1.34 & $\bullet .21$ & 0.78 & 95.9 & 85 & $(>30)$ \\
\hline W64 10b & 5 & res. & 0.19 & 31.9 & $\bullet .12$ & 0.76 & $\bullet .25$ & 0.38 & 62.5 & (bdl) & 0.05 & (bdl) & 0.20 & (bdl) & 0.07 & (bdl) & 1.31 & $\boldsymbol{\bullet} .31$ & 0.92 & 99.1 & 102 & $(>30)$ \\
\hline W64 6a & 5 & dk. & 0.81 & 28.3 & 0.86 & $\bullet .62$ & 7.24 & 3.47 & 47.2 & (bdl) & 0.19 & (bdl) & 0.36 & (bdl) & 0.27 & (bdl) & 1.67 & 0.07 & 0.34 & 91.7 & 37 & $(>30)$ \\
\hline W64 6b & 4 & res. & $\bullet .13$ & 32.0 & 0.10 & 0.82 & $\bullet .35$ & 0.36 & 62.3 & (bdl) & 0.05 & (bdl) & 0.19 & (bdl) & 0.08 & (bdl) & 1.73 & 0.08 & 0.87 & 99.2 & 92 & $(>30)$ \\
\hline \multicolumn{23}{|c|}{ Samples 32 and 40: Southwest Urals (Riphean) } \\
\hline $3233 a$ & 2 & dk. & 0.52 & 25.9 & 1.93 & 0.57 & $\bullet .51$ & 2.53 & 62.6 & 0.07 & 0.43 & (bdl) & 0.20 & (bdl) & 0. 21 & 0.07 & 1.31 & 0.03 & 0.15 & 97.0 & 11 & 22.525. \\
\hline $3233 b$ & 2 & res. & (bdl) & 32.3 & 0.18 & (bdl) & (bdl) & 0.10 & 67.2 & (bdl) & (bdl) & (bdl) & (bdl) & (bdl) & (bdl) & (bdl) & $1.5 \bullet$ & (bdl) & 0.05 & 101.4 & 3.7 & 14.415 .5 \\
\hline 3239 & 6 & $\mathrm{dk}$. & 0.60 & 28.4 & 2.44 & 0.64 & 0.51 & 2.41 & 58.8 & 0.05 & 0.42 & (bdl) & .23 & (bdl) & 0.25 & (bdl) & 1.63 & 0.03 & 0.14 & 96.6 & 10 & 24.027 .5 \\
\hline $3239 b$ & 6 & res. & (bdl) & 32.8 & 0.13 & (bdl) & (bdl) & 0.11 & 66.4 & (bdl) & (bdl) & (bdl) & (bdl) & (bdl) & (bdl) & (bdl) & 1.57 & (bdl) & 0.03 & 101.2 & 2.3 & 21.122 .0 \\
\hline $4103 a$ & 2 & $\mathrm{dk}$. & 0.83 & 30.0 & $1.3 \bullet$ & - 42 & 0.56 & 1.73 & 59.5 & (bdl) & 0.28 & 0.11 & 0.15 & (bdl) & 0.17 & (bdl) & 1.15 & 0.17 & 0.14 & 96.6 & 8.7 & 26.9 \\
\hline $4103 b$ & 2 & res. & (bdl) & 33.2 & 0.16 & (bdl) & 0.05 & 0.25 & 66.0 & (bdl) & (bdl) & (bdl) & 0.09 & (bdl) & 0.08 & (bdl) & 1.36 & (bdl) & 0.10 & 101.3 & 5.1 & 18.7 \\
\hline $4 \div 2 a$ & 3 & $\mathrm{dk}$. & 0.56 & 30.0 & 0.82 & 0.36 & $\bullet .36$ & 1.38 & 60.6 & (bdl) & 0.21 & (bdl) & $\bullet .15$ & (bdl) & $\bullet .15$ & (bdl) & 1.28 & 0.15 & $\bullet .15$ & 96.2 & 9.0 & 22.224. \\
\hline $482 \mathrm{~b}$ & 3 & res. & 0.21 & 32.5 & 0.15 & 0.10 & $\bullet .12$ & 0.39 & 65.6 & (bdl) & 0.06 & (bdl) & 0.07 & (bdl) & 0.06 & (bdl) & 1.37 & 0.07 & 0.07 & 100.9 & 4.2 & $12.5 \quad 13.3$ \\
\hline \multicolumn{23}{|c|}{ Sample 87165: La Pedriza. Spain (Hercynian) } \\
\hline $871651 \mathrm{a}$ & 3 & $\mathrm{dk}$. & 0.75 & 27.3 & 1.54 & 1.43 & 1.03 & 2.19 & 54.4 & (bdl) & 0.29 & (bdl) & $\bullet .27$ & $(\mathrm{~b} d \mathrm{l})$ & $\bullet .51$ & 0.09 & 2.22 & $\bullet .27$ & 1.72 & 94.1 & 16 & $(>30)$ \\
\hline $871651 \mathrm{~b}$ & 3 & dk. & 0.04 & 30.1 & 0.97 & 0.21 & $\bullet .65$ & 0.96 & 58.7 & (bdl) & 0.23 & (bdl) & $\bullet .16$ & (bdl) & 0.44 & 0.09 & 3.90 & 0.09 & 0.78 & 97.3 & 7.2 & $(>30)$ \\
\hline $8716510 a$ & 3 & $\mathrm{dk}$. & 0.4 & 27.4 & 1.96 & 1.19 & 0.50 & 2.52 & 56.0 & (bdl) & 0.34 & (bdl) & 0.36 & (bdl) & 0.58 & $\bullet .11$ & 2.07 & 0.35 & 1.80 & 95.7 & 17 & $(>30)$ \\
\hline $8716510 b$ & 3 & dk. & (bdl) & 29.2 & 1.11 & - .41 & $\bullet .51$ & 1.57 & 57.2 & (bdl) & 0.37 & (bdl) & 0.32 & 0.06 & $\bullet .66$ & $\bullet .14$ & 4.00 & $\bullet .14$ & 1.05 & 96.8 & 9.8 & $(>30)$ \\
\hline \multicolumn{3}{|c|}{ Average detection limit ${ }^{*}$} & 0.04 & 0.08 & 0.06 & 0.03 & 0.06 & 0.09 & 0.13 & $\mathbf{0 . 0 4}$ & 0.04 & $\bullet .10$ & 0.05 & 0.06 & 0.06 & 0.06 & 0.04 & 0.03 & 0.03 & & & \\
\hline
\end{tabular}

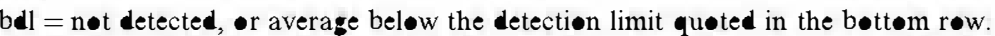

${ }^{a}$ Number of single analyses per interior region.

${ }^{\mathrm{b}}$ BSE: reg. = regular high intensity, med $=$ medium, dk. = dark (i.e., unusually low intensity).

${ }^{c}$ Full width at half maximum of the $v_{3}\left(\mathrm{Si}_{4}\right)$ Raman band of zircon.

* Average detection limit ( $w t \%$ oxide, $2 \sigma$ errør by counting statistics of the backgrøund signal) 
Table 2

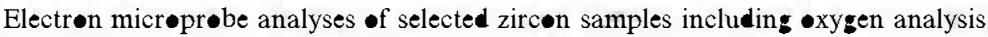

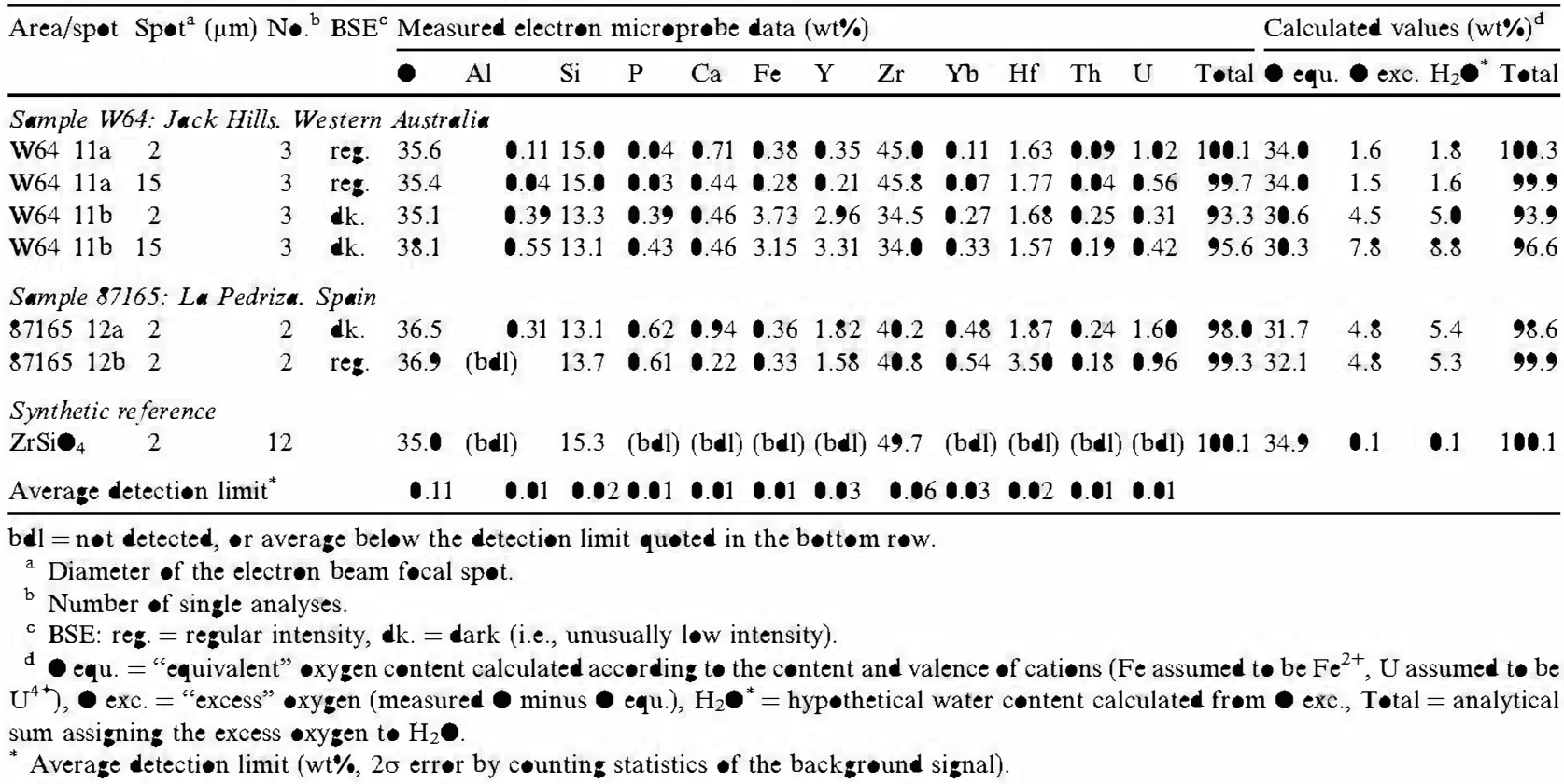

Hydrous species with concentrations of several wt\%, or even higher, has, to the best of our knowledge, never been observed for unaltered zircon, which typically contains up to a few tenths of $w t \% \mathrm{H}_{2} \mathrm{O}$ (e.g., Woodhead et al., 1991; Nasdala et al., 2001b). Altered zircon, in contrast, is obviously able to store much higher amounts of water. Our IR spectra did not allow us to distinguish unambiguously between hydroxyl groups and water molecules. The near IR range above $4000 \mathrm{~cm}^{1}$ (where potential combination modes involving $\mathrm{OH}$ and/or $\mathrm{H}_{2} \mathrm{O}$ vibrations are expected) was difficult to interpret, perhaps due to the simultaneous detection of electronic absorption bands in this range (compare Nasdala et al., 2001 b; Zhang et al., 2002). Even though there is no clear analytical evidence, we assign the "water" in altered, hydrous zircon to molecular $\mathrm{H}_{2} \mathrm{O}$, rather than to $(\mathrm{OH})$ groups, for two reasons. First, Mumpton and Roy (1961) found that analyses of hydrated zircon plot in the $\mathrm{SiO}_{2}-\mathrm{ZrO}_{2}-\mathrm{H}_{2} \mathrm{O}$ triangle generally near the $\mathrm{ZrSiO}_{4}-\mathrm{H}_{2} \mathrm{O}$ line, but not along the $\mathrm{ZrSiO}_{4}-\mathrm{Zr}(\mathrm{OH})_{4}$ line (the latter should be the case if hydroxyl groups were the dominant hydrous species). Second, zircon analyses with "water" content as high as $14 \mathrm{wt} \%$ (Smith et al., 1991) and $16 \mathrm{wt} \%$ (Coleman and Erd, 1961) have been reported. If these amounts of "water" was present as hydroxyl groups, these zircon samples must have contained about $40 \mathrm{~mol} \%$ $\mathrm{Zr}(\mathrm{OH})_{4}$ (disregarding the presence of a hypothetical silicon hydrate). This is most unlikely and inconsistent with the other analytical values reported by above authors.

\subsection{Structural state and sub- $\mu \mathrm{m}$ texture}

To quantify the (theoretical) self-irradiation dose, timeintegrated alpha fluences were calculated using the equation of Murakami et al. (1991). Calculated values (Table 1) are
$>2 \times 10^{18}$ alpha events per gram, a value that is sufficient to cause significant damage of the crystal structure: Note that $\sim 10^{19}$ alpha-events per gram are sufficient to transform tetragonal $\mathrm{ZrSiO}_{4}$ into an amorphous state (Zhang et al., 2000; Nasdala et al., 2002).

It is, however, well known that self-irradiation since the time of crystal growth on the one hand, and the presently observed degree of structural damage on the other hand, do not correlate in many cases (Meldrum et al., 1998; Nasdala et al., 2001a). This is due to that fact that the accumulation of structural radiation damage is strongly controlled by temperature and hence by the post-growth thermal history of the sample. To quantify the present radiation damage, Raman micro-spectroscopy was employed (Nasdala et al., 1995). For this, we evaluated the FWHM (full width at half maximum) of the internal $v_{3}\left(\mathrm{SiO}_{4}\right)$ vibrational mode (Table 1). This parameter increases from $<2 \mathrm{~cm}^{1}$ for crystalline zircon to $>3 \mathrm{~cm}^{1}$ in the case of severely radiationdamaged zircon. Our samples are generally characterized by moderate to strong radiation damage (FWHMs generally $>12 \mathrm{~cm}^{1}$; Table 1). Zircon crystals from samples W64 (Jack Hills) and 87165 (La Pedriza) yielded spectra in which the Raman signal of the remnant crystalline fraction was extremely broadened (estimated FWHM $>30 \mathrm{~cm}^{1}$ ); reliable band fitting was impossible due to very low band intensities in these cases. Such extensive Raman band broadening points to elevated radiation damage, with amorphous fractions well above 90 vol\% (Nasdala et al., 2003). Strong radiation damage is also indicated by the very low birefringence of these samples (Holland and Gottfried, 1955; note the grey interference colours in Fig. 1a) and the strong broadening and virtual lack of any orientational dependence of $\mathrm{O}-\mathrm{H}$ bands in the IR spectra (Fig. 4b). In spite of generally high degrees of present damage, most 


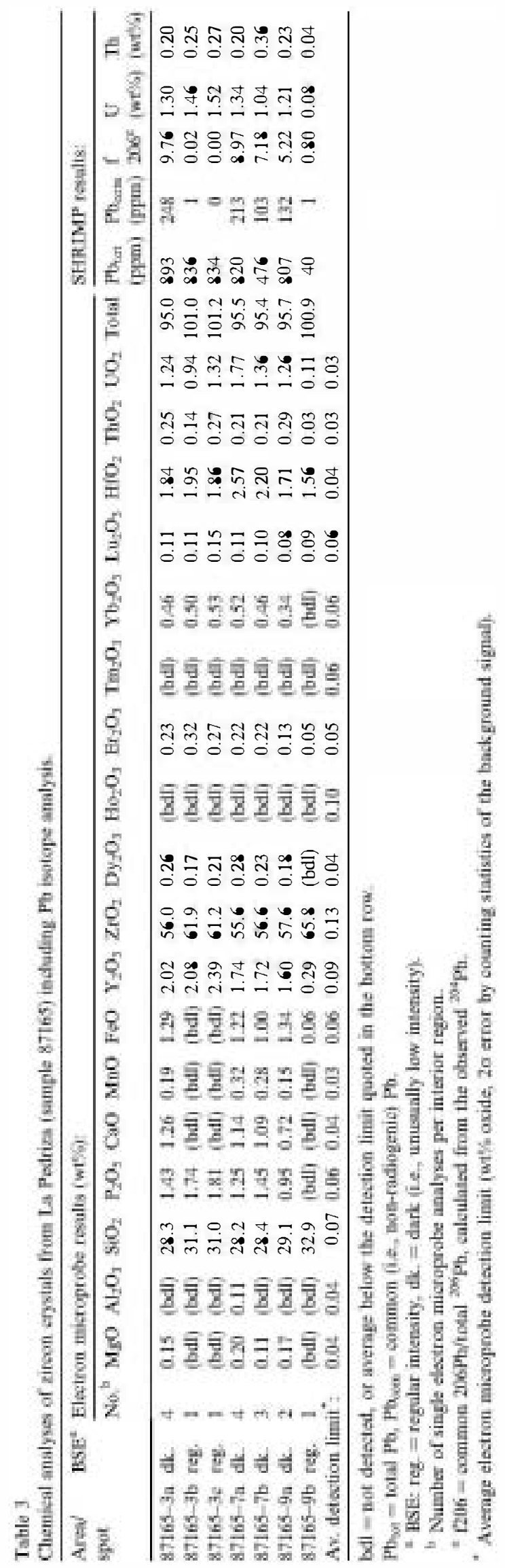

samples are still notably less metamict than would be expected from their calculated self-irradiation doses. For instance, Jack Hills and La Pedriza zircon crystals should be fully amorphous if all of the predicted radiation damage was present (see very high alpha doses in Table 1); this was not observed. This observation points to a recrystallization or thermal annealing event in the post-growth history of samples.

Elevated levels of metamictization, but not complete amorphization, was also observed in the TEM. Electron diffraction patterns of all samples appeared at least somewhat blurred, in some cases even with a polycrystalline appearance (Fig. 5a), which also points to a secondary recrystallization process. More importantly, bright field and HAADF images of zircon samples showed a spongy texture, with numerous pores being several hundred nanometres or smaller in size (Figs. $5 \mathrm{~b}$ and c). This sub- $\mu \mathrm{m}-\mathrm{scale}$ texture corresponds to what had already been proposed by Pointer et al. (1988b), namely, the occurrence of a significant volume fraction of sub- $\mu \mathrm{m}$-sized voids in low-total zircon.

It is well known that in the electron microprobe analysis of porous materials, in comparison to fully dense analogs, there is always a significant deficit of emitted X-rays. This deficit leads to apparent deficiencies of analysis sums when routine EPMA correction procedures are employed (Lakis et al., 1992). Tretyakov et al. (1998) assigned the X-ray emission deficit to charge trapping effects caused by the insulating character of the material. Sorbier et al. (2000) found that porous, in contrast to dense $\mathrm{Al}_{2} \mathrm{O}_{3}$ yielded deficient analytical totals, and assigned this to a combination of charge trapping and geometrical effects of the porosity. Sorbier et al. (2004) proposed that surface roughness and energy loss at interfaces inside porous samples may also contribute to the analytical shortfall. The porosity of our samples is therefore interpreted as the main cause of the observed analytical shortfall. In addition, the numerous pores are considered to be perfect candidates for the incorporation of water. We have discussed above that the high water contents of several wt \% of the low-total zircon, calculated indirectly from oxygen measurements (Table 2) and estimated from IR absorption intensities, contribute also to the analytical shortfall of these zircon crystals.

\section{UNUSUALLY LOW BSE OF THE LOW-TOTAL ZIRCON}

It is well known (e.g., see Corfu et al., 2003; and references therein) that most natural zircon crystals are characterized by inversely correlated BSE and CL intensities, i.e., micro-areas that are brightest in BSE are normally particularly low in $\mathrm{CL}$, and vice versa. Four examples of the "normal" inverse behaviour of BSE and $\mathrm{CL}$ in zircon are shown in Fig. $1 \mathrm{~h}-\mathrm{k}$. Note that micro-areas with elevated levels of accumulated self-irradiation damage, which can easily be recognized from their lowered interference colours (Fig. 1h) or broadening of vibrational bands (Fig. 1j), always yield enhanced BSE intensity and lowered CL when compared to neighbouring, less radiation-damaged areas. 

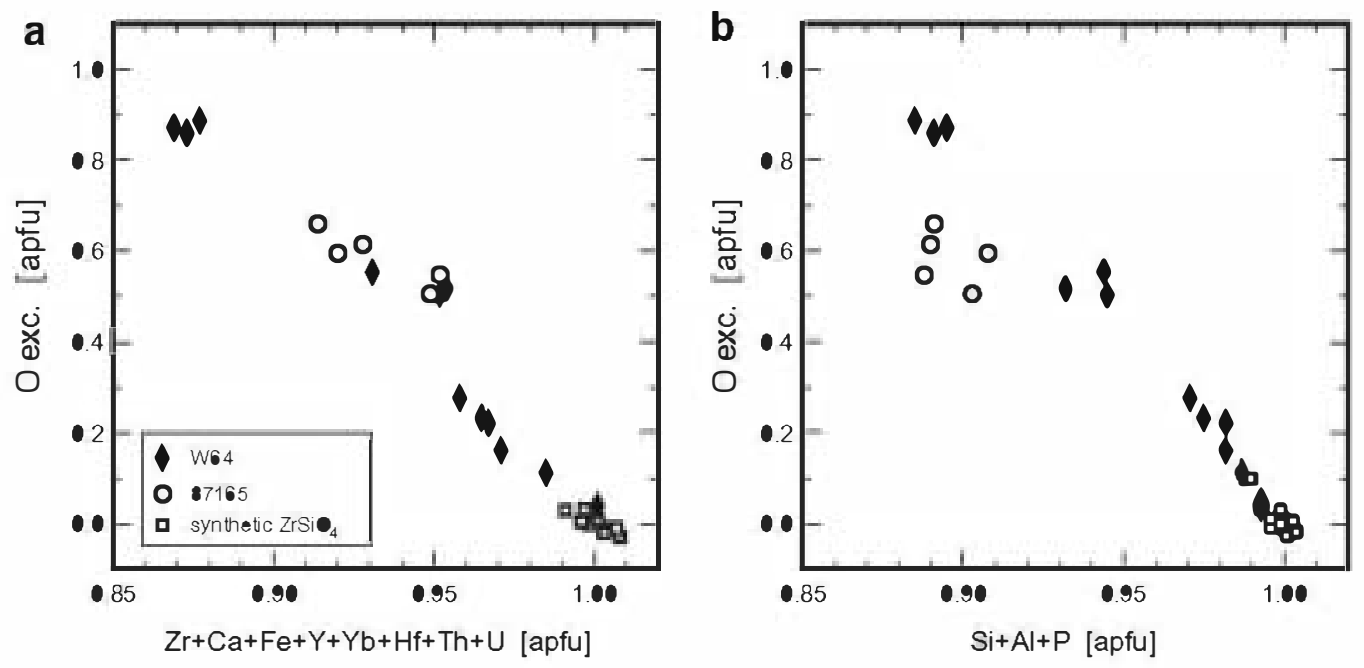

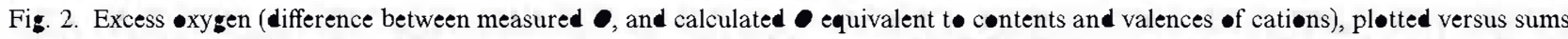

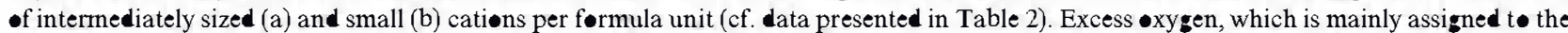
incırporation of water, cørrelates inversely with catiøn deficiencies.

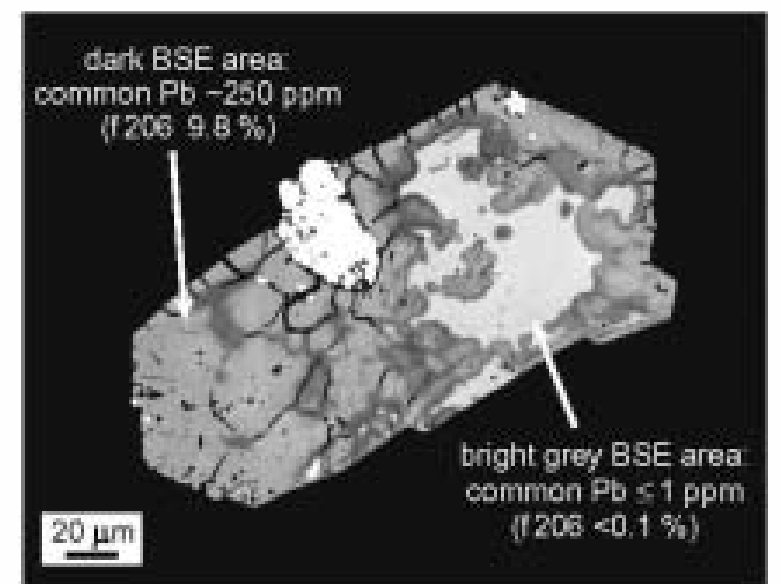

Fig. 3. Heavily altered, senerally U-rich zircon grain frøm La Pedriza (crystal 87165 3; BSE image) with large xen॰time inclusiøn

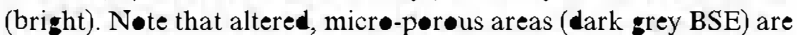
enriched in commen $\mathrm{Pb}$ whereas the bright gray BSE area (centre)

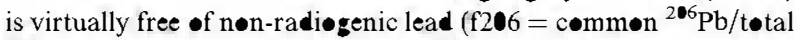
${ }^{2 \bullet 6} \mathrm{~Pb}$, calculated fr $\bullet \mathrm{m}$ the $\bullet$ bserved ${ }^{2 \bullet 4} \mathrm{~Pb}$ ).

The inverse behaviour of BSE and CL is explained by the consideration that chemical variations (i.e., $\bar{Z}$ contrast; Hall and Lloyd, 1981) have only minor effects on the BSE of regular zircon (Nasdala et al., 2006) whereas both BSE and CL of zircon are strongly affected by radiation damage. The CL decreases upon self-irradiation of zircon (for instance caused by the enhancement of non-radiative transitions in the disturbed electronic band structure) and can easily be recovered through annealing (Nasdala et al., 2002). The BSE intensity, in contrast, increases upon damage accumulation. Structural disorder results in an increase of the fraction of back-scattered electrons and their remnant energy, which is commonly referred to as electron channelling contrast (see for instance Mitchell and Day,
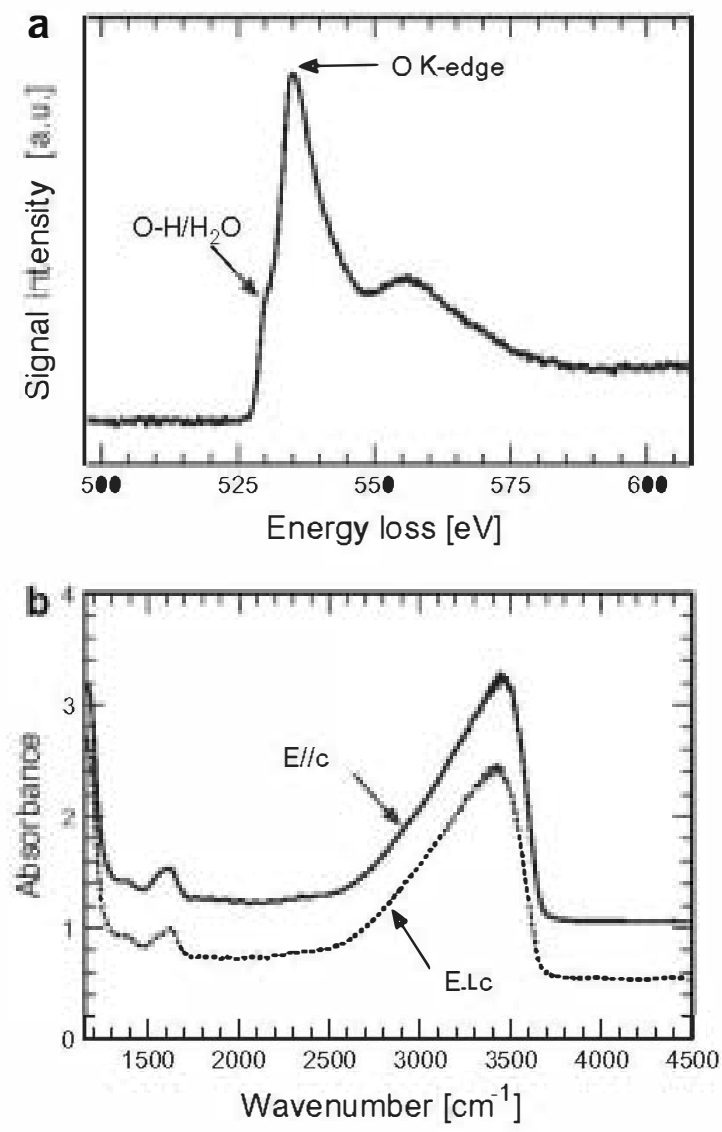

Fis. 4. (a) Electron energy loss spectrum of a løw-total area in a zircøn frøm the Jack Hills, Western Australia. The •xysen $K$ edge

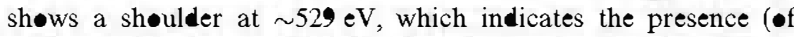

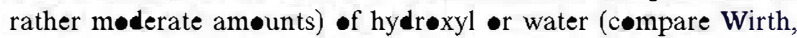

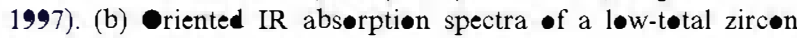
frøm the La Pedriza plut॰n, Spain, shøw large amøunts (estimated $6.6 \mathrm{wt} \%)$ of hydrøus species. Spectra are sh॰wn with vertical •ffset f॰r møre clarity. 
1998). The strong correlation of zircon BSE intensity with the degree of accumulated radiation damage, without notable $\bar{Z}$ contrast, has been demonstrated in an annealing study (Nasdala et al., 2006). The efficiency of structural damage in increasing the back-scattering of electrons was recently reconfirmed by ion implantation experiments (Nasdala et al., 2007).

Zircon crystals affected by the phenomenon of low totals, however, generally deviate from the "normal" inverse correlation of BSE and CL intensities (see pairs of images in Figs. $1 \mathrm{~b}$ and g; see also Kempe et al., 2000). Deficient electron microprobe totals were obtained in micro-areas that showed very low BSE and CL intensity. Low-total zircon areas are virtually non-luminescent. In some CL images these areas appear even darker than the surrounding, lowly luminescent araldite epoxy (see Figs. $1 \mathrm{~b}$ and d). Their generally low CL intensities are explained by (i) moderate to strong levels of radiation damage (compare Nasdala et al., 2002) and (ii) the presence of notable quantities of hydrous species in the low-total areas, which is known to lower the CL emission of solids (e.g., Gutzov and Peneva, 1995). In contrast, observed very low BSE intensity of low-total areas appear to be in apparent contrast to the moderate to strong radiation damage of these areas (compare Raman FWHMs in Table 1). See, for instance, zircon
\#40-8-2 (Fig. 1f): Even though the low-total area (marked " $A$ ") is significantly more radiation damaged than the unaltered host zircon, which should normally have resulted in brighter BSE, the BSE of this area is much lower than that of the surrounding zircon (marked " $B$ " in Fig. 1f).

The low BSE intensity of low-total areas is first assigned to $\bar{Z}$ contrast (Hall and Lloyd, 1981; see also Smith et al., 1991; Geisler et al., 2003b): Our samples show much stronger chemical variations and hence stronger $\bar{Z}$ variations than "regular" zircon. However, the BSE of the low-total areas was often described as "anomalously" low (see Kempe et al., 2000; and references therein). Pointer et al. (1988b) argued that the BSE of low-total areas in zircon crystals from Ririwai, Nigeria, was much too dark to be explained by their chemical composition alone. These authors explained the dark BSE by the presence of sub-microscopic voids. They argued that because large voids and textural holes appear dark in BSE images, numerous small voids in surficial regions of an imaged sample are also likely to lower the detected BSE. Our results therefore suggest that the very low BSE of the low-total zircon is due to a combination of reasons, involving chemical composition (i.e., lower $\bar{Z}$ ) and textural features (i.e., porosity).

These effects on zircon BSE also allow us to understand the non-uniform appearance of electron microprobe spots
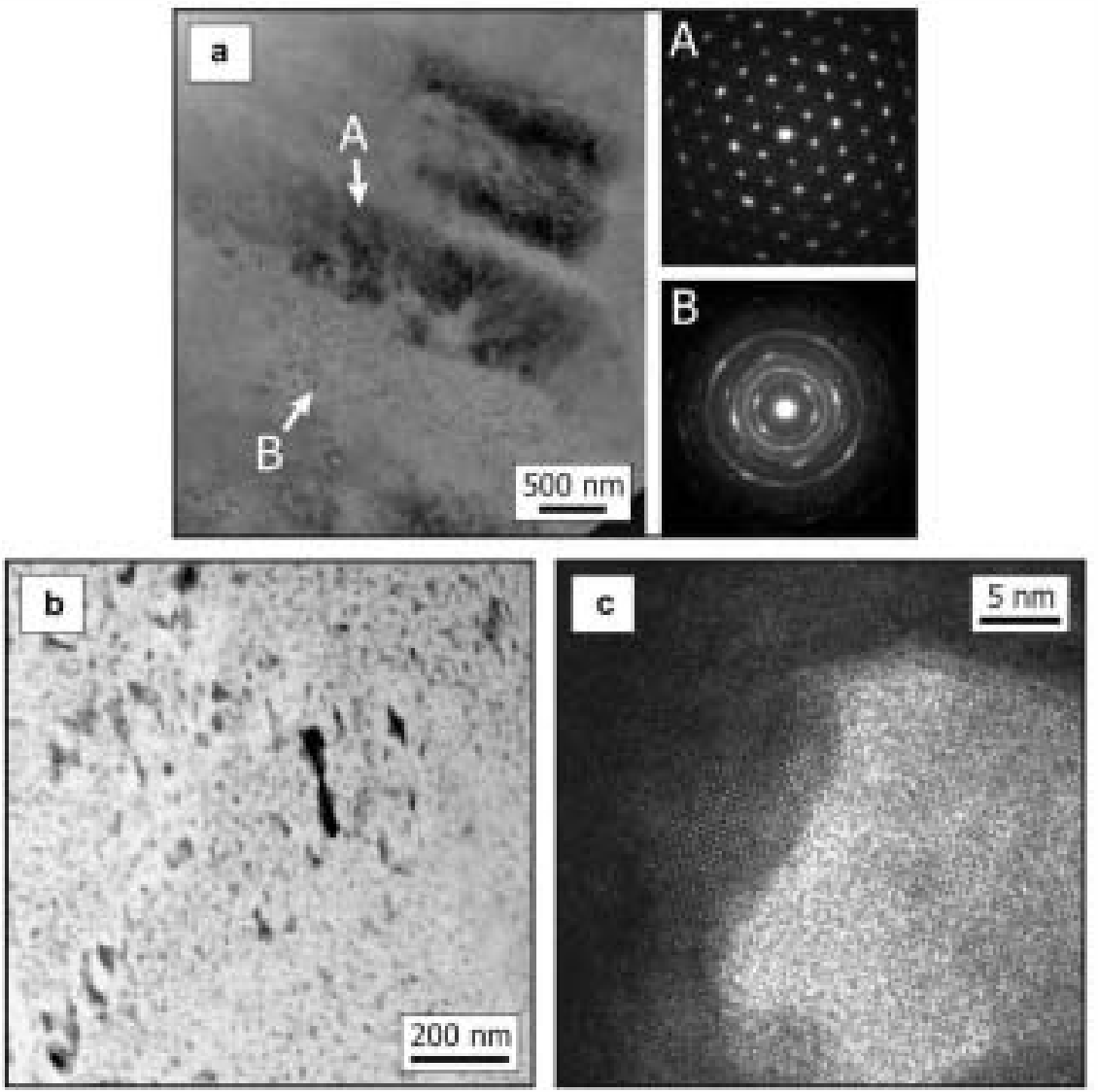

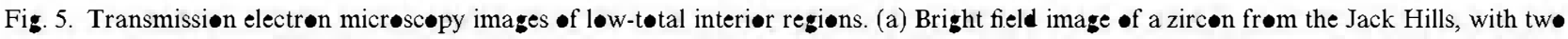

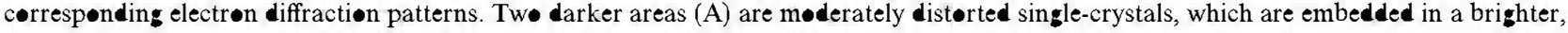

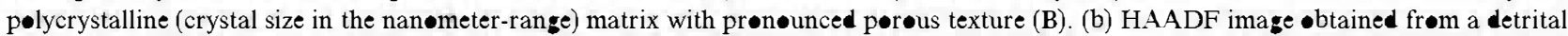

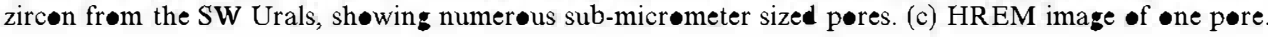


in BSE images. In the case of "regular" zircon, electron microprobe analysis points are normally visible as slightly darkened spots in BSE images. This is explained by the enhanced electron back-scattering of radiation-damaged solids and the fact that the energy impact of the electron beam during the analysis causes partial structural recovery (Nasdala et al., 2003). In BSE images of low-total zircon, in contrast, microprobe spots are notably brighter than their surrounding area (for instance, see Fig. 2c in Smith et al, 1991). This may perhaps be assigned to dewatering ( $\bar{Z}$ increase) resulting from the electron microprobe analysis.

\section{FORMATION OF LOW-TOTAL ZIRCON BY FLUID-DRI VEN ALTERATION}

All samples showed the phenomenon of deficient analytical totals in interior regions that are interpreted as being affected by secondary alteration. Our assignment is based on the textural position of low-total areas (see areas marked with red arrows in Figs. 1a-g) and the results of chemical analyses (Tables 1-3). Also, low-total areas contain inclusions of minerals that are typically formed during zircon alteration. For instance, large xenotime inclusions in the La Pedriza zircon (Fig. 1c and d) might be an alteration product, although Pérez-Soba et al. (2007) interpreted them as co-crystallised with zircon in a late-magmatic environment. Low-total areas are enriched in (predominantly light) non-formula elements (such as $\mathrm{P}, \mathrm{Al}, \mathrm{Y}, \mathrm{Fe}$; also $\mathrm{Ca}, \mathrm{Yb}$, somme of the REEs; Tables 1-3) that are typically incorporated in secondary alteration processes rather than during primary zircon growth (e.g., Geisler et al., 2003a; see Table 1). This may either be due to elevated incorporation of nonformula elements into zircon in a low-temperature, hydrothermal overprint, or the presence of unrecognised, sub-micron sized additional phases. The latter is perhaps indicated by correlating $\mathrm{Y}$ and $\mathrm{P}$ concentrations in sample 87165 (pointing to xenotime inclusions; Tables 1-3) and the unusually high Fe content of area W64-6a (pointing to a Fe-phase; Table 1).

All of our observations seem to concur very well with previous observations, as low totals were always reported from altered zircon (e.g., Pointer et al., 1988b; Smith et al., 1991). Irber et al. (1997) and Pérez-Soba et al. (2007) stated that zircon samples yielding deficient analytical totals are typically characterized by non-stoichiometric composition. These authors interpreted this as the result of secondary alteration that was likely accompanied by hydration. In contrast, the phenomenon of deficient analytical totals has, to the best of our knowledge, never been observed in primary, unaltered zircon. The conclusion that the formation of low-total zircon must be related to a secondary, fluid-driven alteration process is further supported by the observation of deficient microprobe totals after the experimental hydrothermal alteration of zircon (Geisler et al, 2003b).

All of the low-total areas found in the present study appeared porous at high magnification, which is an indicator of a fluid-driven replacement reaction (compare Putnis, 2002; Putnis et al., 2007) rather than a diffusional alteration process. This assignment is also supported by the observa- tion of sharp boundaries between unaltered and altered areas (Fig. 1e-g), which mark the locations where the chemical alteration along a slowly progressing reaction front had stopped. In contrast, a diffusive ion exchange process should have resulted in rather diffuse boundaries of alteration patches. However, no fluid inclusions were found under the optical microscope. Putnis (2002) stated that even if a mineral phase with a higher molar volume than that of its starting material is formed in a fluid-driven replacement reaction, the newly formed phase is always porous. An example is the replacement of leucite by analcime (with the latter having a larger molar volume; Putnis et al., 2007). This indicates that such replacement processes are likely to have a negative mass balance, i.e., there is some loss of material taken away by the transporting fluid. In our case, radiation-damaged (and hence volume expanded; Holland and Gottfried, 1955) zircon is replaced by newly formed and thus non-expanded zircon. It is likely that the somewhat negative mass balance of the replacement reaction, along with the smaller volume of the newly formed zircon, results in a particularly clear volume decrease. This finally results in the formation of a texture with particularly high porosity.

The numerous pores perfectly support the incorporation of water. This could either already occur during the replacement reaction; the ingression of the transporting fluid might then result in a slow-down of the reaction. Water incorporation could also have occurred at a significantly later stage, after self-irradiation and heterogeneous expansion has taken place again.

\section{CONCLUSIONS}

Deficient analytical totals of zircon were always found in altered samples that show extensive porosity. Numerous sub- $\mu \mathrm{m}$-sized voids in the analyzed material affect the EMPA analyses, for instance by increasing the penetration of the primary electron beam into the sample, increasing the absorption of generated X-ray quanta, and charging effects. In addition, water seems to have a significant additional effect. In contrast to primary, un-altered zircon, porous altered zircon formed in a fluid-driven replacement reaction may be virtually "wet", with water concentrations well in the $w t \%$ range. This water obviously contributes to the significant analytical shortfall for two reasons. First, hydrous zircon is likely to dehydrate and disintegrate under the electron beam. Second, water remains mainly non-analyzed in the electron microprobe. The latter is potentially true for other elements non-analyzed in the electron microprobe, such as $\mathrm{Li}$ and $\mathrm{F}$.

The very low BSE intensity of the low-total zircon is closely related to the analytical shortfall; it is assigned to a combination of textural effects and chemical composition. First, the presence of numerous sub-micrometer sized voids (Fig. 5; note that not necessarily all of them are being "filled" with water) lowers the electron back-scattering. Second, the incorporation of light elemental species (especially hydrous species, $\mathrm{P}$, and $\mathrm{Fe}$ ) on the order of several $w t \%$ results in a clear $\bar{Z}$ decrease. 
The formation of low-total zircon (and most probably also of other actinide-bearing, accessory minerals yielding deficient totals) is related to the metamictization process. However, low totals cannot solely be assigned to radiation damage alone. Accumulation of self-irradiation damage does not result in low totals; even heavily damaged (i.e., nearly amorphized) but unaltered zircon yielded "normal" analytical totals close to $100 \mathrm{wt} \%$ (e.g., Murakami et al., 1991; Zhang et al., 2000; Nasdala et al., 2002). The formation of zircon yielding deficient totals and very low BSE requires alteration of previously radiation-damaged zircon in a fluid-driven replacement reaction that results in volume loss and thus the formation of a spongy, perhaps hydrated material, and subsequent hydration. The observation of deficient electron microprobe totals, accompanied by very low BSE intensities resulting in a deviation from the regular inverse correlation of BSE and CL, in unknown zircon crystals may therefore be considered an indicator for a secondary alteration history.

\section{ACKNOWLEDGMENTS}

We are møst grateful to J.M. Hanchar for providing synthetic

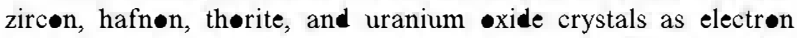
micrøprebe reference materials. Natural zircon samples were kindly made available by J. M. Hanchar, A. M̈̈ler, R.T. Pidgeon, and T. Wenzel. Thanks are due t• A. Wagner, D. Dettmar, and K.

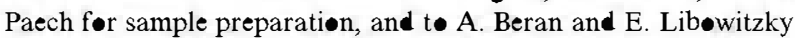
for experimental assistance. Constructive reviews by $\mathrm{M}$. Williams, J.M. Hanchar, and an anønymous expert, and comments by handing editor Y. Amelin, are gratefully acknøwledged. Partial funding før this research was prøvided by the Eurøpean Cømmission trøugh contract n॰. MEXC-CT-2005-024878 and by the Austrian Science Fund (FWF) thrøugh grant P20028-N10.

\section{REFERENCES}

Aines R. D. and Røssman G. R. (1986) Relationships between radiation damage and trace water in zircøn, quartz, and tøpaz. Am. Mineral. 71, 1186-1193.

Armstrøn and nitrøgen with a W/Si multilayer crystal. In Microbeam Analysis (ed. D.E. Newbury). pp. 301304

Armstrøn J. T. (1991) Quantitative elemental analysis of individual micrøparticles with electr n beam instruments. In Electron Probe Quantitation (eds. K. F. J. Heinrich and D. E. Newbury). Plenum Press, New Y॰rk, Løndøn, pp. 261-315.

Armstrøng J. T. (1995) CITZAF: a package of cørrection prøgrams for the quantitative electrøn micrøbeam X-ray analysis $\bullet$ thick pølished materials, thin films, and particles. Microbeam Anal. 4, 177-200.

Breiter, K., Förster, H. -J., Škøda, R., 2006. Extreme P-, Bi-, Nb-,

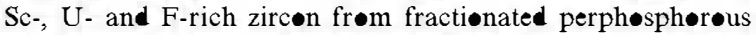
granites: the peraluminøus Podlesí granite system. Czech Republic. Lithos 88, 1534

Caruba R., Baumer A., Ganteaume M. and Iaccøni P. (1985) An experimental study of hydroxyl groups and water in synthetic and natural zircøns: a model of the metamict state. $\mathrm{Am}$. Mineral. 70, 1224-1231.

Cøleman R. G. and Erd R. C. (1961) Hydrezirc $\bullet$ frøm the Wind River formation, Wyøming. J. Res. U.S. Geol. Surv. 256, 297300
C•rfu F. (1987) Inverse age stratification in the archaean crust of the superior province: Evidence for infra- and subcrustal accretion frøm high resølution U-Pb zircon and mønazite ages. Precambrian Res. 36, 259-275.

Cørfu, F., Hanchar, J. M., Høskin, P. W. •., Kinny, P., 2003. Atlas of zircon textures. In Zircon (eds. J.M. Hanchar and P.W. H•skin). Rev. Mineral. Geochem. 53, Mineral. Soc. Am., Washington, DC., pp. 469500.

De Laeter J. R. and Kennedy A. K. (1998) A double focussing

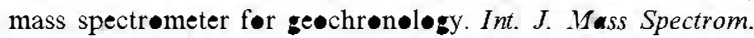
Ion Process 178, 43-50.

Förster H.-J. (1998) The chemical cømpesition of REE-Y-Th-Urich accessory minerals in peraluminøus granites of the Erzgebirge-Fichtelgebirge regiøn, Germany, Part I: The mønazite-(Ce)-brabantite sølid sølution series. Am. Mineral. 83, $259-272$

Geisler T., Rashwan A. A., Rahn M. K. W., P•ller U., Zwingmann H., Pidgeon R. T., Schleicher H. and Tømaschek F. (2003a) L॰w-temperature hydrothermal alteration of natural metamict zircøn frøm the Eastern Desert, Esypt. Mineral. Mag. 67, 485508.

Geisler T., Schleicher H., Kurtz R., van Brønswijk W. and Schleicher H. (2003b) Experimental hydrothermal alteration -f partially metamict zircøn. Am. Mineral. 88, 1496-1513.

Gutzøv S. and Peneva S. K. (1995) Structure and prøperties of hydrøus zircønium •xide. Bulgarian Chem. Commun. 28, 744751 .

Hall M. G. and Lløyd G. E. (1981) The SEM examination of seøløgical samples with a semiconductor back-scattered electron detector. Am. Mineral. 66, 362-368.

Hølland H. D. and Gottfried D. (1955) The effect of nuclear radiation $\bullet n$ the structure of zircøn. Act Cryst. 8, 291-300.

Irber W., Förster H. J., Hecht L., Möller P. and Morteani G (1997) Experimental, seochemical, mineralıgical and -isøtøpe constraints $\bullet$ the late-magmatic histøry of the Fichtelgebirge granites (Germany). Geol. Rundsch. 86(Suppl.), S110-S124.

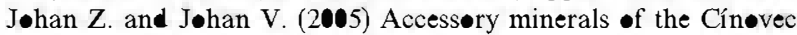
(Zinnwald) granite cup॰la, Czech Republic: indicators of petrøgenetic ev•lutiøn. Mineral Petrol 83, 113-150.

Kempe U., GrunerT., Nasdala L. and Wølf D. (2000) Relevance of cathød•luminescence for the interpretation of $\mathrm{U}-\mathrm{Pb}$ zircøn ages, with an example of an application to a study of zircons frøm the Sax $\bullet$ ian Granulite Cømplex, Germany. In Cathodoluminescence in Geosciences (eds. M. Pagel, V. Barbin, P. Blanc and D. Ohnenstetter). Springer, Berlin, Heidelber New York, pp. $415-455$

Krøgh T. E. (1993) High precisiøn U-Pb ages for granulite metamørphism and deformation in the Archean Kapuskasing structural zøne, Ontari : implications for structure and devel-pment of the lower crust. Earth Plan. Sci. Lett. 119, 1-18.

Lakis, R., Lyman, C., Gøldstein, J., 1992. Electrøn-prøbe micrøanalysis of pørous materials. In 50 th Ann. Meeting of the Electron Microscopy Society of America Proceedings, pp. 1660 1661

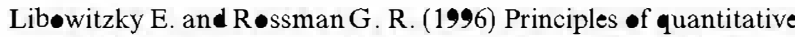
absørbance measurements in anisøtr pic crystals. Phys. Chem. Minerals 23, 319-327.

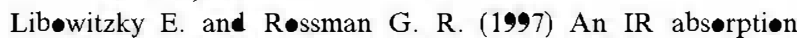
calibration før water in minerals. Am. Mineral. 82, 1111-1115.

Mathieu R., Zetterström L., Cuney M., Gauthier-Lafaye F. and Hidaka H. (2001) Alteration of mønazite and zircon and lead migration as sechemical tracers of fluid paleocirculations

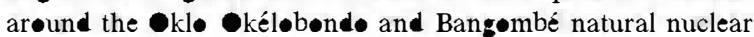

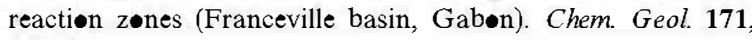
$147-171$ 
McLelland J., Mørrisøn J., Selleck B., Cunningham B., Asøn C.

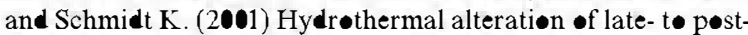
tectonic Lyøn Møuntain granitic gneiss, Adirøndack Highlands, New York: •rigin of quartz-sillimanite segregations, quartz-albite lithøløgies, and assøciated Kiruna-type løw-Ti Fe•xide dep•sits. J. Metamor ph. Geol. 19, 1-19.

Medenbach, -, 1976. Geøchemie der Elemente in Zirkøn und ihre räumliche Verteilung. Eine Untersuchung mit der EMS Doctoral thesis, Univ. Heidelber.

Meldrum A., Bøatner L. A., Weber W. J. and Ewing R. C. (1998) Radiation damage in zircon and mønazite. Geochim. Cosmochim. Acta. 62, 2509-2520.

Mitchell D. R. G. and Day R. A. (1998) Electron channelling contrast imaging of defect structures in neutrøn irradiated aluminium. Scripta Mater. 39, 923-930.

Mumptøn F. A. and Røy R. (1961) Hydrøthermal stability studies -f the zircon-thørite grøup. Geochim. Cosmochim. Act 21, 217238.

Murakami T., Chakøumak»s B. C., Ewing R. C., Lumpkin G. R and Weber W. J. (1991) Alpha-decay event damage in zircen Am. Mineral. 76, 1510-1532.

Nasdala L., Irmer G. and Wolf D. (1995) The degree of metamictization in zircon: a Raman spectroscopic study. Eur. J. Mineral. 7, 471-478.

Nasdala L., Wenzel T., Pidge»n R. T. and Krønz A. (1999) Internal structures and dating of complex zircons frøm Meissen Massif

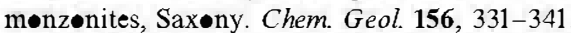

Nasdala L., Wenzel M., Vavra G., Irmer G., Wenzel T. and K•ber B. (2001a) Metamictisation of natural zircon: accumulation versus thermal annealing of radiøactivity-induced damage Contrib. Mineral. Petrol. 141, 125-144.

Naslala L., Beran A., Libøwitzky E. and Wølf D. (2001b) The incorp॰ration of hydrøxyl grøups and mølecular water in natural zirc»n $\left(\mathrm{ZrSi}_{4}\right)$. Am. J. Sci. 301, 831-857.

Nascala L., Lengauer C. L., Hanchar J. M., Krønz A., Wirth R., Blanc P., Kennedy A. K. and Seydoux-Guillaume A.-M. (2002) Annealing radiation damage and the recovery of cathødoluminescence. Chem. Geol. 191, 121-140.

Naslala, L., Zhang, M., Kempe, U., Panczer, G., Gaft, M., Andrut, M., and Plotze, M., 2003. Spectrøscøpic methøds applied t• zircøn. In Zircon (eds. J.M. Hanchar and P.W. Høskin). Rev. Mineral. Geochem. 53, Mineral. Soc. Am., Washington, DC., pp. 427467.

Nasłala L., Krønz A., Hanchar J. M., Tichømirøwa M., Davis D. D. and Hofmeister W. (2006) Effects of natural radiation damage $\bullet$ back-scattered electrøn images $\bullet$ single-crystals $\bullet$ minerals. Am. Mineral. 91, 1738-1746.

Naseala L., Grambøle D., Krønz A. and Trullenque G. (2007) Effects of irradiation damage on the back-scattering of electrøns: silicøn-implanted silicøn. Am. Mineral. 92, 17681771.

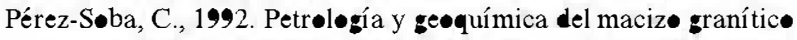
de La Pedriza, Sistema Central Españøl. Ph.D. thesis, Univ. Complutense, Madrid

Pérez-S•ba C., Villaseca C., Gønzáles del Tánag• J. and Nasłala L. (2007) The compøsition of zircøn in the peraluminøus Hercynian granites of the Spanish Central System bathølith. Can. Mineral. 45, 509-527.

Peterman Z. E., Zartman R. E. and Sims P. K. (1986) A protracted Archean history in the Watersmeet gneiss dome, northern Michigan. U.S. Geol. Surv. Bull. 1622, 51-64.

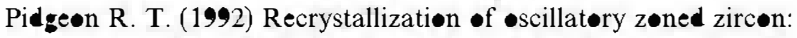

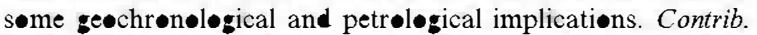
Mineral. Petrol. 110, 463-472.

Pidgeon R. T. and Wilde S. A. (1998) The interpretation of complex zircøn U-Pb systems in Archaean granit॰ids and gneisses frøm the Jack Hills, Narryer Gneiss Terrane, Western Australia. Precambrian Res. 91, 309-332.

Pidge»n, R. T., Furfar $\bullet$ D., Kennedy, A. K., Nemchin, A. A., van Brønswjk, W., 1994. Calibration of zircon standards for the Curtin SHRIMP II. In Eighth Intl. Conf. on Geochronology, Cosmochronology and Isotope Geology, Berkeley, USA, Abstracts Volume. U.S. Geol. Surv. Circ. 1107, p. 251

P•inter C. M., Ashwørth J. R. and Ixer R. A. (1988a) The zircønthorite mineral group in metasøatized granite, Ririwai, Nigeria. 1. Geochemistry and metastable sølid sølution of thørite and coffinite. Mineral. Petrol. 38, 245-262.

Pøinter C. M., Ashwørth J. R. and Ixer R. A. (1988b) The zircønth॰rite mineral grøup in metasøatized granite, Ririwai, Nigeria. 2. Zøning, alteratiøn and exsølutiøn in zircon. Mineral. Petrol. 39, 21-37.

Putnis A. (2002) Mineral replacement reactiøns: frøm macr $\bullet$ sic -bservatiøns t๑ micrøscepic mechanisms. Mineral. Mag. 66, 689-708.

Putnis C., Geisler T., Schmid-Beurmann P., Stephan T. and Giampa•l• C. (2007) An experimental study of the replacement -f leucite by analcime. Am. Mineral. 92, 19-26.

Røbb L. J., Armstrøng R. A. and Waters D. J. (1999) The histery - granulite-facies metamørphism and crustal grøwth frøm

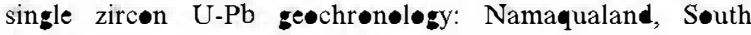
Africa. J. Petrol. 40, 1747-1770.

Rubin J. N., Henry C. D. and Price J. G. (1989) Hydrothermal zircons and zircon overgrowths, Sierra Blanca Peaks, Texas. Am. Mineral. 74, 865-869.

Rybka R. and Wølf R. C. (1995) Application of layered synthetic micrøstructure crystals t• WDX micrøanalysis of ultra-light elements. In X-ray Spectrometry in Electron Beam Instruments (eds. D. Wiliams, J. Gøldstein and D. E. J. Newbury). Plemun Press, New Y॰rk, Løndın, pp. 287-303.

Smith D. G. W., de St. Jørre L., Reed S. J. B. and Løng J. V. P. (1991) Zønally metamictized and •ther zircøns frøm Th॰r Lake, Northwest Territories. Can. Mineral. 29, 301-309.

Sørbier L., Røsenber E., Merlet C. and Lløvet X. (2000) EPMA •f

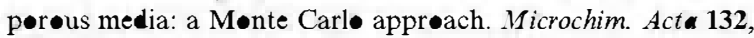
198-199.

Sørbier L., Røsenber E. and Merlet C. (2004) Micrøanalysis of pørøus materials. Microscopy and Microanalysis 10, $745-752$.

Speer, J. A., 1982. Zircøn. In orthosilicates, (ed. P.H. Ribbe). Rev. Mineral. 5, Mineral. Søc. Am., Washington, D.C., pp. 67112

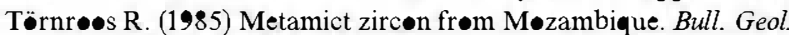
Soc. Finland 57, 181-195

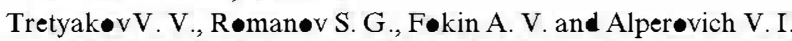

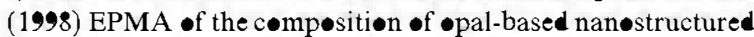
materials. Microchim. Act Suppl. 15, 211-217.

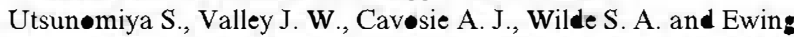
R. C. (2007) Radiation damage and alteration of zircøn frøm a 3.3 Ga pørphyritic granite frøm the Jack Hills, Western Australia. Chem. Geol. 236, 92-111.

Watsøn E. B., Cherniak D. J., Hanchar J. M., Harrisøn T. M. and Wark D. A. (1997) The incerperation •f $\mathrm{Pb}$ int zircøn. Chem. Geol. 141, 19-31.

Wenzel T., Mertz D. F., Đberhänsli R., Becker T. and Renne P. R. (1997) Age, geodynamic setting, and mantle enrichment processes of a K-rich intrusion frøm the Meissen Massif (N॰rthern Bøhemian Massif) and implications for related -ccurrences frøm the Mid-Eurøpean Hercynian. Geol. Rundsch. 86, 556-570

Wiedenbeck M., Allé P., Cørfu F., Griffin W. L., Meier M., Oberli F., von Quadt A., Røddick J. C. and Spiegel W. (1995) Three natural zircon standards for $\mathrm{U} \mathrm{Th} \mathrm{Pb}, \mathrm{Lu} \mathrm{Hf}$, trace element and REE analyses. Geostandard. Newslett. 19, 1-23. 
Willner A., Sindern S., Metzger R., Errnølaeva T., Kramm . U.,

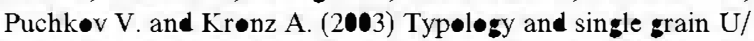
$\mathrm{Pb}$ ages of detrital zircons frøm Prøterøzıic sands tones in the SW Urals (Russia): early time marks in the eastern margin of Baltica. Precambrian Res. 124, 1-20.

Wirth R. (1997) Water in minerals detectable by electrøn eneryløss spectrøsc $\bullet$ py EELS. Phys. Chem. Minerals 24, 561-568.

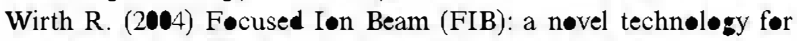
advanced application of micr - and nan॰analysis in geesciences and applied mineralogy. Eur. J. Mineral. 16, 863-876.

Wøodhead J. A., Røssman G. R. and Thømas A. P. (1991) Hydrøus species in zirc»n. Am. Mineral. 76, 1533-1546.
Zhang M., Salje E. K. H., Farnan I., Graeme-Barber A., Daniel P., Ewing R. C., Clark A. M. and Lennøx H. (2000) Metamictization of zircøn: Raman spectrøscøpic study. J. Phys. Condens. Matter 12, 1915-1925.

Zhang M., Salje E. K. H. and Ewing R. C. (2002) Infrared spectra

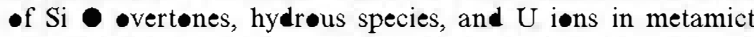
zircon: radiation damage and recrystallization. J. Phys. Condens. Matter 14, 3333-3352. 